\title{
Asymptomatic giant pneumatization of the middle turbinate: A case report
}

\section{Orta konkanın asemptomatik dev pnömatizasyonu: Bir olgu sunumu}

\section{Süha Ertuğrul ${ }^{1}$}

\begin{abstract}
Concha bullosa is a pneumatization of the turbinates at several degrees. Pneumatization of the middle turbinate is generally asymptomatic; however, it may become symptomatic depending on its degree of pneumatization. All giant pneumatizations of the middle turbinate reported in the literature are reported to cause nasal obstruction. In this article, we present a case of asymptomatic giant pneumatization of the middle turbinate that was detected incidentally in a patient who presented with acute tonsillitis infection with sore throat and swallowing difficulty. To the best of our knowledge, this is the first asymptomatic giant pneumatization of the middle turbinate in the literature. In this article, we discussed how pneumatization of the middle turbinate could be symptomatic in the context of this case.

Key Words: Asymptomatic, concha bullosa, giant, middle turbinate, pneumatization

Öz

Konka bülloza, konkaların çeșitli derecelerdeki pnömatizasyonudur. Orta konkanın pnömatizasyonu genellikle asemptomatiktir. Ancak pnömatizasyon derecesine bağlı olarak semptomatik olabilir. Literatürde sunulan tüm orta konka dev pnömatizasyonlarının burun tıkanıklığına neden olduğu bildirilmiştir. $\mathrm{Bu}$ yazıda boğaz ağrısı ve yutma güçlüğü ile başvuran akut tonsillit hastasında rastlantısal saptanan orta konkanın asemptomatik dev pnömatizasyonu olgusu sunulmuştur. Bildiğimiz kadarıyla bu literatürdeki ilk orta konkanın asemptomatik dev pnömatizasyonudur. $\mathrm{Bu}$ yazıda, bu olgu bağlamında orta konka pnömatizasyonunun nasıl semptomatik olabileceğini tartıștık. Anahtar kelimeler: Asemptomatik, konka bülloza, dev, orta konka, pnömatizasyon.
\end{abstract}

11 Department of Otorhinolaryngology, Faculty
of Medicine, Karabuk University, Karabuk,
Turkey.
Informed Consent: The written consent was
received from the patient who was presented in
this study.
Hasta Onamı: Çalışmada sunulan hastadan yazılı
onam alınmıştır.
Conflict of Interest: No conflict of interest was
declared by the authors.
Çkar Çatışmasi: Yazarlar çıkar çatışması
bildirmemişlerdir.
Financial Disclosure: The authors declared that
this case has received no financial support.
Finansal Destek: Yazarlar bu olgu için finansal
destek almadıklarını beyan etmişlerdir.
Geliş Tarihi / Received: 04.06 .2018
Kabul Tarihi / Accepted: 30.06 .2018
Yayın Tarihi / Published: 20.07 .2018
Sorumlu yazar / Corresponding author
Süha Ertuğrul
Sirinevler Mahallesi, Alpaslan Caddesi, No: 1 ,
Merkez, 78200, Karabuk, Turkey.
Phone: +9005058260021
Fax: + 9003704125628
e-mail: drsuhaertugrul@ @otmail.com
Copyright @ ACEM

${ }^{1}$ Department of Otorhinolaryngology, Faculty of Medicine, Karabuk University, Karabuk, Informed Consent: The written consent was this study.

Hasta Onamı: Calıșmada sunulan hastadan yazılı Conflict of Interest: No conflict of interest was declared by the authors.

Cıkar Catıșması: Yazarlar çıar çatıșması

Financial Disclosure: The authors declared that this case has received no financial support. destek almadıklarını beyan etmişlerdir.

Kabul Tarihi / Accepted: 30.06.2018

Süha Ertuğrul

Merkez, 78200, Karabuk, Turkey.

Phone: +9005058260021

Fax: +9003704125628

Copyright $(\odot$ ACEM 


\section{Introduction}

Concha bullosa is a pneumatization of the turbinates at several degrees and it is one of the most frequently seen variations of the nasal cavity [1]. Approximately 55\% of the cases have the anterior and the posterior ethmoid cells that are held responsible for the pneumatization of the middle turbinate (PMT) for about $45 \%$ of them [2]. Middle turbinate has functions such as olfaction, humidifying the air and regulating the air flow [3]. PMT is generally asymptomatic; however, it becomes symptomatic depending on its degree of pneumatization and its relation with adjacent structures [4]. The most frequent symptoms include nasal obstruction, headache and olfactory disorder. All giant PMT reported in the literature are reported to cause nasal obstruction $[4,5]$.

In this article, we presented a case of asymptomatic giant PMT that was detected incidentally in a patient who presented with acute tonsillitis infection with sore throat and swallowing difficulty.

\section{Case report}

A 28-year-old female patient presented to our clinic with the symptom of sore throat and swallow difficulty. Acute tonsillitis infection was observed on the oropharyngeal examination and antibiotherapy was started. She did not have a nasal obstruction, headache, postnasal discharge and olfactory disorder. But her anterior rhinoscopic examination showed a mass with mucosal surface blocking the nasal passage in both nasal cavities. When an endoscopic examination was performed, it was seen that the middle turbinates in both nasal cavities were large. Especially in the left nasal cavity, it was observed that the middle turbinate extended down to the nasal base (Figure 1a). The paranasal computerized tomography scan that was taken showed that both middle turbinates were extremely pneumatized with the left side being more pneumatized (Figure 1b). The sinus aeration was normal. As it was asymptomatic, no intervention was planned for PMT.

Written informed consent was obtained from the patient.

Figure 1. A. Endoscopic view of the left nasal cavity (IT: inferior turbinate, MT: middle turbinate, S: septum). B. Coronal computed tomography showing the over pneumatization of the bilateral middle turbinates (single star: right pneumatization of the middle turbinate, double star: left pneumatization of the middle turbinate).
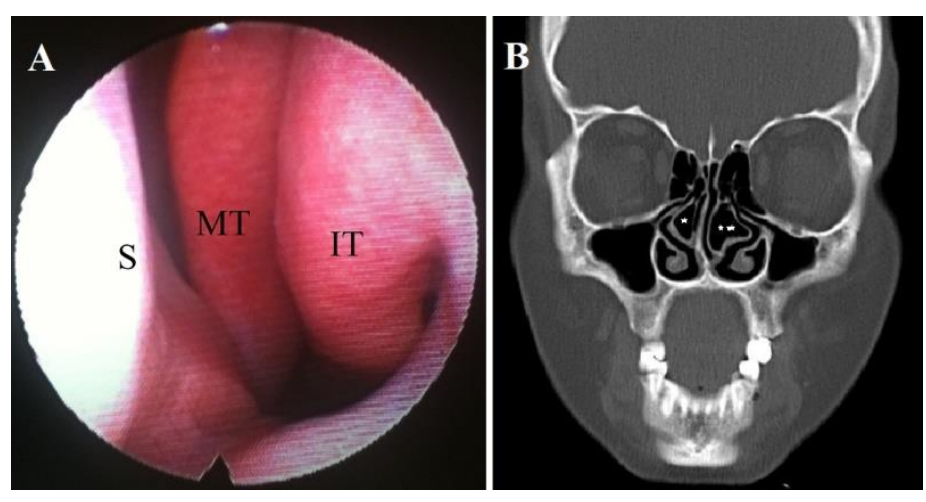

\section{Discussion}

The incidence of PMT is in the range of $13 \%-53 \%[1,2$, 6]. Bolger et al. [1] classified PMT as lamellar, bullous and extensive depending on the degree of pneumatization and localization. Accordingly, they defined pneumatization on the vertical lamella of the middle turbinate as lamellar type, on the inferior segment of the middle turbinate as bullous type and on the entire middle turbinate as extensive type. Our case had a PMT of the extensive type [1].

Even though the development mechanism of PMT has not been fully elucidated, various theories have been brought forward. According to one theory (ex vacuo), the vacuum formed at the opposite side of deviation after the development of a septum deviation and the air flow pattern of the nasal cavity trigger the development of PMT. Uzun et al. [7] reported that the incidence of PMT was increased in patients with advanced septum deviation in such a way as to support this theory in their study of 140 cases. According to a second theory, it is defended that the development of PMT is not related to septum deviation, but to the aeration of middle turbinate. The study conducted by Uygar et al. [8] actually supports the second theory. The fact that our case had bilateral PMT and not a septal deviation suggests that the second theory is more valid.

PMT is generally asymptomatic; however, it becomes symptomatic depending on the degree of pneumatization or its relation with adjacent structures. All giant PMT's reported in the literature are reported to cause nasal obstruction [4, 5]. In our case, the PMT did not cause nasal obstruction, even though it reached the nasal base. It is not right to associate symptoms with only the degree of pneumatization. Concomitant septum deviation or inferior turbinate hypertrophy can lead to nasal obstruction, sinusitis attacks if ventilation and drainage of the osteomeatal complex are disturbed, or contact headache if contact with surrounding tissues. If there are no such events, they may be asymptomatic even at giant sizes, as in our case. We conclude that the association of PMT with surrounding tissues is more important than the degree of pneumatization in the symptomatic case of PMT.

In conclusion, the middle turbinates may reach gigantic proportions, which sometimes extend to the nasal base, as a result of extreme pneumatization. However, PMT can be asymptomatic even if it reaches giant dimensions.

\section{References}

1. Bolger WE, Clifford AB, Parsons DS. Paranasal sinus bony anatomic variations and mucosal abnormalites: CT analysis for endoscopic sinus surgery. Laryncoscope. 1991;101:56-64.

2. Zinreich SJ, Mattox DE, Kennedy DW, Chisholm HL, Diffley DM, Rosen $\neg$ baum AE. Concha bullosa: CT evaluation. J Comput Assist Tomogr. 1988;12:778-84.

3. Lee HY, Kim CH, Kim JY, Kim JK, Song MH, Yang HJ, et al. Surgical anatomy of the middle turbinate. Clin Anat. 2006;19:493-6.

4. Yigit O, Cinar U, Uslu B, Dadas B. Giant concha bullosa: A case report. Kulak Burun Bogaz Ihtis Derg. 2004;13:77-9.

5. Derin S, Deveer M, Sahan M, Beydilli H. Giant concha bullosa. BMJ Case Rep. 2014 Jan 15;2014. doi: 10.1136/bcr-2013-200524.

6. Unlu HH, Akyar S, Caylan R, Nalca Y. Concha bullosa. J Otolaryngol. 1994;23:23-7.

7. Uzun L, Savranlar A. Pneumatization of the middle turbinate: a computed tomography study in 140 Patients. KBB ve BBC Dergisi. 2004; 12:54-8.

8. Uygur K, Tüz M, Doğru H. The correlation between septal deviation and concha bullosa. Otolaryngol Head Neck Surg. 2003;129:33-6. 